\title{
Miasto jako obiekt „ideologicznego” zarządzania logistycznego
}

\section{The city as an object of "ideological" logistics management}

\begin{abstract}
Decyzje logistyczne, podejmowane w ramach logistyki miasta, wydają się mieć raczej obiektywny charakter. Obserwacje funkcjonowania miast wskazują jednak na coś zupełnie innego - u podstaw tych decyzji znajdujemy przesłanki ideologiczne. Artykuł poświęcony jest temu właśnie zagadnieniu.

\section{Słowa kluczowe:}

logistyka miasta, ideologia, zarządzanie logistyczne, pomysł na miasto
\end{abstract}

\begin{abstract}
Logistics' decisions taken as a part of the city logistics tend to be rather objective in their nature. Observations of the functioning of cities, however, indicate something completely different - at the basis of these decisions we find ideological premises. The paper is dedicated to this issue.

Key words:

city logistics, ideology, logistics management, idea for a city
\end{abstract}

str. 2-7

\section{Bibliografia}

Calvino, I. (1975). Niewidzialne miasta. Warszawa: Czytelnik.

Czajkowski, R., Nowakowski, W. (2016). IoT jako naturalna ewolucja Internetu. Elektronika. Konstrukcje, Technologie, Zastosowania, 57(4), 28-32.

International Trade Administration. (2016). Export opportunities. Smart Cities, Regions \& Communities. https://www.trade.gov/mar- kets/smartcities.pdf (27.06.2019).

Fundacja Panoptykon. (2012). Monitoring $w$ polskich miastach $i w$ oczach spoleczeństwa. Warszawa: Fundacja Panoptykon. https://panop- tykon.org/sites/default/files/publikacje/panoptykon_cctv_seminarium_10-10-2012_2.pdf (24.05.2017).

Fundacja Panoptykon. (2016). Zabawki Wielkiego Brata. Warszawa: Fundacja Panoptykon. https://panoptykon.org/sites/ default/files/publikacje/fundacja_panoptykon_zabawki_wielkiego_brata_przewodnik.pdf (27.06.2019).

Gutowski, B. (2006). Przestrzeń marzycieli. Miasto jako projekt utopijny. Warszawa. Kołakowski, L. (2004). Mini wyktady o maxisprawach. Kraków: Znak.

Kotus, J. (2007). Natura wielkomiejskich sąsiedztw. Analiza subsąsiedzkich i sąsiedzkich terytorialnych podsystemów spotecznych $w$ Poznaniu. Poznań: Wydawnictwo Naukowe UAM.

Lefebvre, H. (2012). Prawo do miasta. Praktyka Teoretyczna, (5), 183-197.

Mack, R. W., Snyder, R. C. (1957). The Analysis of Social Conflict. Toward of Overview and Synthesis. The Journal of Conflict Resolution, 1(1), 212-248.

Mucha, J. (1978). Konflikt i spoleczeństwo: z problematyki konfliktu spolecznego we wspótczesnych teoriach zachodnich. Warszawa: PWN.

Nawratek, K. (2012). Dziury w catym. Wstęp do miejskich rewolucji. Warszawa: Wydawnictwo Krytyki Politycznej.

Sowa, J. (2014). Miejsca przecięcia. W: R. Perez de Arce Antoncich (i in). Synchronizacja. Projekty dla miast przyszłości. My i oni. Przestrze- nie wspólne / projektowanie dla wspólnoty. Warszawa: Fundacja Bęc zmiana.

Reykowski, J. (2007). Procesy grupowe a rozwiązywanie antagonistycznych konfliktów: Czy idea demokracji deliberatywnej może mieć psy- chologiczny sens? Psychologia Społeczna, 2(4), 97-119.

Reykowski, J. (2011). Sprzeczność interesów jako źródło konfliktów. Nauka, (3), 7-38.

Seliger, M. (1976). Ideology and Politics. London: Allem and Unwin.

Sudjic, D. (2017). Język miast. Kraków: Wydawnictwo Karakter.

Szafrańska, E., Kaczmarek, J. (2007). Percepcja przestrzeni - pomiędzy prawdą a autentycznością. W: M. Madurowicz (red.). Percepcja wspótczesnej przestrzeni miejskiej, Warszawa: Uniwersytet Warszawski. 
Szczepański, J. (1965). Elementarne pojęcia socjologii. Warszawa: PWN.

Szołtysek, J. (2011). Kreowanie mobilności mieszkańców miast. Warszawa: Wolters Kluwer.

Szołtysek, J. (2016). Logistyka miasta, Warszawa: PWE.

Szołtysek, J., Brdulak, H., Kauf, S. (2016). Miasto dla pieszych. Idea czy rzeczywistość. Warszawa: Texter.

Szołtysek, J. (2017a). Logistyka miasta wobec postulatów zwiększania „inteligencji” smart city. Przedsiębiorczość i Zarządzanie, $18(8), 285-296$.

Szołtysek, J. (2017b). Ideologia w logistyce. Gospodarka Materiałowa i Logistyka, (8), 2-6.

Szołtysek, J. (2018). Miasto w dobie Internet of Things. W: Ł. Sułkowski, D. Kaczorowska-Spychalska (red.). (2018). Internet of Things. Nowy paradygmat rynku. Warszawa: Difin.

Szołtysek, J. (2019). Mobilność metropolitalna - konsensus, kompromis czy wola większości. W: Wyzwania programowe dla Górnośląsko--Zagłębiowskiej Metropolii. (w druku).

Waszkiewicz, P. (2012). Monitoring wizyjny miejsc publicznych w dużym mieście na przykładzie Warszawy. Próba analizy kosztów i zysków. Archiwum Kryminologii, (34), 253-274. 